S.A. Vorontsov, Doctor of Sciences (Law), Professor of the Procedural Law Department, South-Russian Institute of Management, Branch of the Russian Presidential Academy of National Economy and Public Administration

A.V. Ponedelkov, Doctor of Sciences (Politics), Professor, Honored Scientist of the Russian Federation, Head of the Political Science and Ethnopolitics Department, South-Russian Institute of Management, Branch of the Russian Presidential Academy of National Economy and Public Administration

\section{THE THIRD}

ALL-RUSSIAN

ELITOLOGICAL

CONGRESS WITH

INTERNATIONAL

PARTICIPATION

"RUSSIAN ELITOLOGY:

INNOVATIVE

RESPONSES

TO THE CHALLENGES

OF THE MODERN

WORLD”

(Rostov-on-Don, 15-16 February 2019)
С.А. Воронцов, доктор юридических наук, профессор кафедрь процессуального права Южно-российского института управления - филиала Российской академии народного хозяйства и государственной службь при Президенте РФ (email:raven_serg@mail.ru)

А.В. Понеделков, доктор политических наук, профессор, заслуженньй деятель науки РФ, заведующий кафедрой политологии и этнополитики Южно-россииского института управления - филиала Российской академии народного хозяйства и государственной служби при Президенте РФ (email: ponedelkov@skags.ru)

\section{Третий Всероссийский} элитологический конгресс «РОССИЙСКАЯ ЭАИТОАОГИЯ: ИННОВАЦИОННЫЕ ОТВЕТЫ НА ВЫЗОВЫ СОВРЕМЕННОГО МИРА»

\author{
(г. Ростов-на-Аону, \\ 15-16 феврамя 2019 г.)
}

$\Upsilon$ ретий элитологический конгресс «Российская элитология: инновационные ответы на вызовы современного мира» состоялся 15-16 февраля 2019 г. в Ростове-на-Аону. Конгресс продолжиц традицию ростовской научной элитологической школы, заложенную Первым Всероссийским элитологическим конгрессом «Элитология России: современное состояние и перспективы развития» (2013 г.) и Вторым Всероссийским элитологическим конгрессом «Элитология и стратегии развития современной России» (2016 г.) по изучению соџиацьного стату- 
са, роли и базовых характеристик современной российской правящей элиты, тенденций и проблем ее развития и функционирования.

Аанное мероприятие проведено в соответствии с резолюџией конгресса Российского общества политологов (РОП), состоявшегося в сентябре 2018 г. В ходе конгресса, в котором приняли участие признанные эксперты и выдающиеся ученые России, была сформирована эффективная система обмена научными мнениями и налажено комплексное сотрудничество по актуальным вопросам, связанным с элитологическими исследованиями.

В качестве организаторов-соучредителей Конгресса выступили обшероссийская общественная организаџия «Российское общество политологов» и ее региональные отдекения: Ростовской, Астраханской, Волгоградской, Саратовской областей, Пятигорское отдемение, Российская ассоџиация политической науки, Академия политической науки, факультет политологии МГУ, Ааборатория пробцем повышения эффективности государственного и муниџипального управление ЮРИУ РАНХиГС, Пятигорский государственный университет, Карачаево-Черкесский государственный университет имени У.А. А^иева, Общественная палата Ростовской области и Аругие. Активное участие в организации конгресса и обсуждении проблем современной элитологии приняли ученые различных институтов РАНХиГС, в том числе Поволжского института управления имени П.А. Столыпина.

На конгрессе были представлены доклады известных ученых, за которыми последовала острая полемика в ходе офиџиальных дискуссий и кулуарного общения участников. На пленарном засеАании выступили доктор политических наук, профессор кафедры российской политики МГУ А.П. Кочетков; Аоктор политических наук, профессор кафеАры политологии и политического управления РАНХиГС А.Н. Тимофеева; доктор политических наук, профессор кафедры государственной политики МГУ А.И. Соловьев; директор Института междисциплинарных исследований глобальных процессов и глокализации РИНХ Аоктор политических наук, профессор А.М. Старостин; доктор исторических наук, профессор кафеАры политических наук Поволжского института управления имени П.А. Столыпина В.М. Аолгов, декан факультета соџиологии и политологии Финансового Университета при Правительстве РФ кандидат политических наук А.Б. Шатимов и Аругие ученые.

В Южно-Российском институте управления Российской академии народного хозяйства и государственной службы (ЮРИУ РАНХиГС) последовательно разрабатывается научное направление элитологии по изучению соџиального статуса, роли и базовых характеристик современной российской правящей элиты, тенденџий и пробцем ее развития и функџионирования. Изучение этих проблем осуществляется в контексте современных соџиально-политически процессов, ибо развитие элитологии особенно актуально в странах, где происходит смена элит, характеризующихся слабостью и низким качеством. При этом формирование политической элиты, обладающей высокими управменческими и нравственными качествами, является одним из условий выхода из кризиса.

В рамках подготовки к Третьему Всероссийскому конгрессу, в июле - нояб- 
ре 2018 г., Аабораторией проблем повышения эффективности государственного и муниципального управления Южно-Российского института управления Российской академии народного хозяйства и государственной службы при Президенте РФ проведено соџиологическое исследование в пятнадџати субъектах Европейской части Российской Федерации. В ходе социологических опросов использовалась методика, аналогичная исследованиям 2013 и 2016 гг, проведенных при подготовке к первому и второму конгрессам.

Целью исследования явмялся анализ состояния современной элиты российских регионов, выявление роли мидеров обшественного мнения в политическом процессе. Результаты исследования позволили выделить следующие аспекты, касающиеся региональных элит. По мнению экспертов - государственных деятелей, журналистов, ученых, депутатов, представителей политических партий, - элита региона сформирована федеральной властью из чисма влиятельных мюдей. Такого мнения придерживаются 44,0\% экспертов в Ростовской области, 50\% - в Краснодарском крае, 60,2\% - в Московской области. Современная политическая элита представлена в основном бывшей номенклатурой, сменившей прежнюю идеологическую принадмежность, а новая генераџия, как правило, состоит в родственных отношениях с пре Ашествующей (этого мнения придерживаются 50,7\% экспертов в Московской области, 40,0\% - в Ростовской области). Следует отметить, что термин «быв-

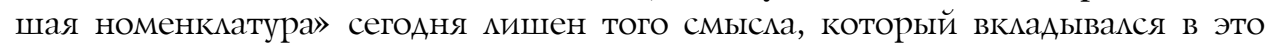
понятие в 1990-е годы.

Эксперты обращают внимание на то, что процесс формирования региональной элиты по-прежнему явмяется результатом внутриэлитных договоренностей и следствием «работы» клановых политико-управленческих отношений. Так полагают 50,7\% экспертов в Московской области, 42\% - в Ставропольском крае, $34 \%$ - в Ростовской обцасти. Аишь $18 \%$ экспертов в Ростовской области и в Аругих субъектах РФ уверены, что формирование региональной элиты осуществмяется на основе демократических проџеАур превентивной политики. Существенно снизилось число экспертов, считающих, что в регионах у власти находятся творческие и активные цюАи, обладающие искренним желанием изменить хоА событий в кучшую сторону, усилия которых блокируются высшей государственной властью и коррумпированными структурами (8\% - в Ростовской области; 4,2\% - в Московской области; 3,3\% - в Республике Карелия).

Аля системного понимания процессов, связанных с элитой как со среАой, гАе осуществляется проџесс разработки и принятия ключевых решений, сравним результаты исследований 2016 и 2018 гг. Оџенки, данные экспертами Ростовской области, сопоставимы с оценками экспертов в Аругих субъектах Федерации. Так, в ответах экспертов на вопрос: «Какие меры вы бы преАможили дмя улучшения качественных характеристик современной правящей российской эмиты?» - выявмено снижение значимости фактора антикоррупционного очищения с 49,5 Ао 46,0\%. Можно преАположить, что общество отмечает определенную результативность принимаемых антикоррупционных мер, а также факт достаточно широкого освещения в СМИ процессов, связанных с пресечением коррупџионных преступлений должностных Аиџ. 
По данным социологического опроса, наиболее значимыми показатемя-

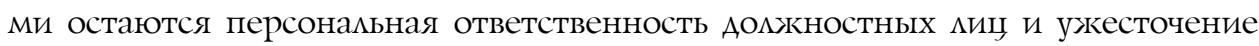
спроса за некачественное исполнение служкебных обязанностей (58,0\%). Респонденты подчеркивают необходимость ухода от фактической анонимности политической вмасти к ее профессионацьной персонификации и ответственности за результат управленческой работы. Аалеко не все политические события явцяются слеАствием осуществления полномочий органов государственной власти, необходимо учитывать и более широкий набор психологических, политико-экономических и социальных факторов. Аемонстрация могущества, связанная с сосредоточением потоков социальных благ в руках правящей политико-административной элиты, безусловно, повышает ее политические рейтинги и делает социальное положение оппонентов политической элиты, способных оспорить ее статусные позиции, не более чем статистической погрешностью. ОАнако в кризисные периоды у правящей соџиальной элиты не получается распределить ответственность и тем самым защитить себя от критики. В массовом политическом сознании власть всегда считается ответственной за происходящее.

Расхождение результатов проведенных соџиологических исследований наблюдается в вопросе о дебюрократизации государственного аппарата. Так, в 2016 г. на необходимости проведения дебюрократизаџии управления настаивали 36,9\% экспертов, в 2018 г. - 16,0\%. Такой результат можно интерпретировать следующим образом. Определенные Аействия по дебюрократизаџии уже предпринимались: например, оптимизация штатного расписания госуАарственной гражданской службы, сокращение числа государственных служащих, внедрение современных информационных технологий и Аругое. Тем не менее эксперты отметили, что дебюрократизаџия опасна именно в кризисный период. С одной стороны, опасность возникает при выходе на рынок труда большого количества безработных из числа бывших государственных служащих, что формирует проблемы по трудоустройству и усицивает соџиальную напряженность. С Аругой стороны, Аебюрократизаџия влечет ослабление управляемости государственного аппарата, прежде всего снижение «плотности» контромя за работой разцичных сфер обшественной жизни. Согласно исслеАованию, мало изменился и уровень оценки значимости кадровой работы, а также возможности Аобиться кардинального улучшения функционирования системы профессиональной переподготовки и повышения квацификации каАров государственного и муниџипального управления - 24,0\%.

Представляет определенный интерес динамика изменения ответов на вопрос: «Какие достоинства и негативные характеристики проявцяются в деятельности современных российских политико-административных и регионацьных элит?». При анализе полученных результатов выявцяется снижение значимости умения разрешать конфликты с 44,5\% в 2016 г. Ао 38,0\% в настоящее вре-

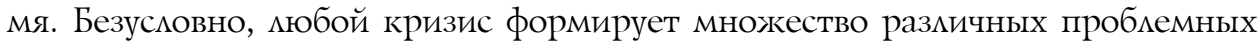
ситуаций, требующих навыков быстрого управленческого реагирования и их эффективного разрешения. Следовательно, могично было ожидать роста данного показателя качества представителей элиты, а не его снижения. Почему

136 Bulletin of the Volga Region Institute of Administration • 2019. Vol. 19. № 3 
же экспертный опрос показал обратный результат? Вероятно, это связано не с переоценкой функций соџиальной элиты, а с изменением понимания сути кризисных проявлений и принџипиальной способности повлиять на них со стороны региональных элит. Конфмикты и цокальные кризисные проявмения на региональном уровне продущируются экономическими и политическими явлениями глобального порядка, повлиять на которые региональная элита не имеет реальной возможности. Этим и обусмовлено снижение качественных оџенок региональной элиты со стороны экспертов. При этом в массовом сознании представление об ответственности региональной политико-административной и бизнес-элиты за все происходящее в данном регионе остается неизменным, и оно достаточно критично.

Изменилась позиция экспертов и по вопросу отношения представителей эмиты к соџиальным проблемам. В 2016 г. этот показатель составцял 13,75\%, а в $2018-6,0 \%$. При этом возросла значимость факторов, связанных с необходимостью жестких и непопулярных решений Аля минимизации посмедствий неопределенности в стратегических рисках. Чуткость, состоящая в принщипе «войти в положение обездоленных, существенно затрудняет принятие подобных политических решений. Несомненно, этот фактор может вызывать дополнительное напряжение в отношениях элиты и народных масс. Разрешить эту коммуникативно-политическую проблему может демонстраџия элитой реального принятия всех издержек кризиса вместе с рядовыми гражданами, не делая попыток создать Аля себя более комфортные условия, используя возможности и статус принадмежности к элите.

Очевидно и расхождение «экспертного» и «народного» понимания данного вопроса. Существует массовый соџиальный запрос на отзывчивость к проблемам граждан; но, по мнению ряда экспертов, это проявление опредеменной слабости, при которой невозможно быстро принимать неприятные, но необходимые решения. Это свидетельствует также о формировании мобимизационного типа общественного сознания, в котором процессы, связанные с санкционными действиями США и ЕС, их последствиями в виде проблем в экономике и падения уровня жизни воспринимаются в обществе как «холоАная война», требующая мобилизационной перестройки политического сознания общества и повышения качества общественных отношений в цемом.

Кризисное состояние повышает актуальность обеспечения единства элиты и народа, способность обычных мюдей с пониманием относиться к непопулярным решениям и принимать неизбежные издержки. В 2013 г. опасность отрыва власти от народа отмечали 27,69\% экспертов, в 2018 г. этот негативный Аля стабимьности общества фактор составиц уже 32,0\%. Огромный разрыв в доходах, соџиальное расслоение, непродуманные законодательные и управменческие инициативы усиливают отчуждение элиты от общества, создают благоприятную среду для политических манипуляџий, порожАают опасные Аля политического строя и государства риски.

Важной функщией правящей элиты явмяется способность проявцять стратегическое предвидение, создавать и реализовывать инновации в различных сферах жизни. Исследование показало определенное недоверие экспертов к 
качеству реализации данной функции представителями элиты, что проявицось в ответах на вопрос «Как бы вы оџеници вкцаА политико-административных эмит в инновационное развитие современной России?».

Подавцяющее большинство экспертов не виАят у элиты необходимых качеств Аля осушествления успешной инноваџионной деятельности. В связи с этим возникает проблема выявления мидеров, способных реализовать общенациональную инноваџионную стратегию развития страны. В ходе проведенного исследования эксперты указали на приоритетные с их точки зрения возможности Аля улучшения отбора и подготовки преАставителей региональной помитико-административной элиты. Отмечается, что необходимость качественного обновления и повышения эффективности политико-административной эмиты видится в привлечении молодых специалистов из числа муниџипацьных и региональных мидеров и активистов, проявцяющих деятельную жизненную позицию. По мнению экспертов, отбор в элиту необходимо проводить на основании оценки итогов мониторинга эффективности работы руководителя, используя проектную работу как способ отбора и подготовки политических мидеров, а также кейсы наставничества, стажкировки и т.п. Следует искоренять такие явления, как сращивание политических сил и местных надзорных органов, «круговая порука», «кумовство», а также стремиться к улучшению системы профессиональной переподготовки и повышения квалификаџии. К отбору в управленческую эмиту целесообразно допускать претендентов, уже проявивших себя на практике и заслуживших авторитет у населения.

Проведенное исследование бымо ориентировано не только на выявление важнейших соџиально-политических характеристик российской региональной политико-административной элиты, но и на опредемение перспективных, по мнению экспертов, направлений развития элитологии в качестве отрасли научного знания. Изучение системы взаимоотношений элиты и широких слоев населения необходимо продолжить с учетом кризисных условий, когАа создается угроза методам взаимодействия, которые в стабильных условиях считаиись эффективными.

Эксперты считают наиболее актуальными дия изучения соџиально-политические вопросы, связанные с межэтническим взаимодействием, безопасностью, образованием, а также аспекты функционирования элиты, связанные с юридической незащищенностью граждан вне круга эмиты. Перспективным направлением соџиологических исследований является рассмотрение особой роли государственной вмасти в формировании российской элиты и воспитании чувства национацьного самосознания. Необходим постоянный анациз специфики внутренней идентификации современных российских элит и Аифференџиации элитного слоя по экономическим и политическим направлениям, изучение механизмов самовоспроизводства и вцияния эмиты на качественный состав элитного слоя общества. 